\title{
POLI wt Allele
}

National Cancer Institute

\section{Source}

National Cancer Institute. POLI wt Allele. NCI Thesaurus. Code C106238.

Human POLI wild-type allele is located in the vicinity of $18 \mathrm{q} 21.1$ and is approximately 52 $\mathrm{kb}$ in length. This allele, which encodes DNA polymerase iota protein, is involved in DNA repair. 